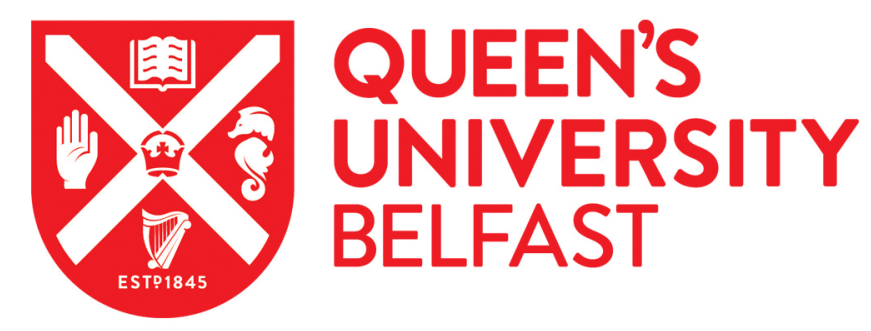

\title{
Community Regeneration: An Elite or a 'Real' Community Space?
}

McAreavey, R. (2009). Community Regeneration: An Elite or a 'Real' Community Space? International Planning Studies, 14(3), 311-327. https://doi.org/10.1080/13563470903481627

\author{
Published in: \\ International Planning Studies
}

Document Version:

Peer reviewed version

Queen's University Belfast - Research Portal:

Link to publication record in Queen's University Belfast Research Portal

\section{Publisher rights}

(C) 2009 Taylor and Francis

This is an Accepted Manuscript of an article published by Taylor \& Francis in International Planning Studies on 15 December 2009 , available online: http://www.tandfonline.com/doi/abs/10.1080/13563470903481627

\section{General rights}

Copyright for the publications made accessible via the Queen's University Belfast Research Portal is retained by the author(s) and / or other copyright owners and it is a condition of accessing these publications that users recognise and abide by the legal requirements associated with these rights.

Take down policy

The Research Portal is Queen's institutional repository that provides access to Queen's research output. Every effort has been made to ensure that content in the Research Portal does not infringe any person's rights, or applicable UK laws. If you discover content in the Research Portal that you believe breaches copyright or violates any law, please contact openaccess@qub.ac.uk. 


\section{Community regeneration: an elite or a 'real' community space?}

Dr. Ruth McAreavey

Lecturer

SPACE

Queen's University, Belfast

David Keir Building

Stranmillis Rd

Belfast

BT9 5AG

Tel: $0044(0) 2890975563$

Fax: $0044(0) 2890663754$

http://www.qub.ac.uk/ep

Email: r.mcareavey@qub.ac.uk 


\title{
Community regeneration: an elite or a 'real' community space?
}

\section{Key words}

Governance, regeneration, power, community

\begin{abstract}
Identifying community interests in processes of planning and regeneration is less than straightforward. By their very nature programmes encourage the development of particular projects, typically relying on experience from past initiatives to inform current practice. One of the difficulties for partners is juggling the need to comply with administrative demands while engaging in a meaningful way with their community. This paper uses empirical evidence to examine power relations within structures of governance. It argues that current processes are unable to identify real community interests and consequently create space that favour elite interests; all of which restrain the impact of governance.
\end{abstract}

\section{Word Count}

8029 


\section{Community regeneration: an elite or a 'real' community space?}

\section{Introduction}

Current literature reveals how processes of governance are central to contemporary planning practice, with participatory programmes assuming a central position (see for example, Miraftab, and McConnell, 2008; Harwood and Zapata, 2006; and Raco et al. 2006). Issues of community and state power have emerged to become heavily debated subjects within this era of governance. As the impact of systems of governance being felt at a global level (OECD, 2001), the policy landscape has changed dramatically. Governance marks the erosion of traditional boundaries, relying on new partners including the community, public and private sector and based on devolved power (Tendler, 1997; Murdoch and Abram, 1998; Rhodes, 1997; Stoker, 1998; Pierre, 2000; Jessop, 2002). In these new partnership arrangements the state does not merely hand power over to the community, but it assumes an altered position in the processes of governance so that 'power and interest are not simply rendered meaningless but are redefined and relocated' (Hajer and Wagenaar, 2003:5). The changed role for government in this approach offers a clue as to where significant analysis might be conducted. Where and how does the central state relocate its power and interest? What is the impact for regeneration actors?

The legitimacy of power conferred on the new 'partners' from the private and civic realm is the subject of an emerging debate within the literature (see for instance Cashore, 2002; Connelly and Richardson, 2004; Shortall, 2005; Goodwin, 2006 and 
Derkzen and Bock, 2009). Less attention has been focused on the implications of systems of governance for communities. It is argued that further knowledge of these relations would contribute to our understanding of the structures and processes of governance (Edwards et al. 2001; Storey 1999; Shortall 2004; Hayward et al., 2004; Pearce et al. 2005).

This paper seeks to examine community involvement in governance by using a project funded under UK government's Single Regeneration Budget. The paper begins by outlining the context for the emergence of regeneration partnerships. The concept of power is examined before moving on to describe the case study in some detail including an overview of the Single Regeneration Budget, background to the area in which the project was developed and analysis of the governance structures that emerged. Finally the conclusions consider the implications for structures of governance, with particular focus on the relationship between the state and other partners.

\section{Decentralisation and regionalisation}

The decentralisation of responsibilities for policy making and delivery has resulted in new political arrangements comprising multi-level and meta-governance (Jessop, 2005; Peters and Pierre, 2001). It signifies a different way of achieving things, a movement from (stable) institutional approaches towards a (fluid) networked form of policymaking (Hajer and Wagenaar, 2003). 
Decentralisation and the reformation of political structures bring the concept of participation centre stage. It enables citizens to more actively participate in structures of 'governance', that is, an institutional framework broader than government, based on the idea of partnership, devolving power, and including the community, public and private sector (Jessop, 1990; Tendler, 1997; Pearce et al. 2005). A proliferation of partnerships between public and civil society sectors stemming from these new governance practices has been evident across the globe (Rhodes, 1997; Lowndes and Skelcher et al., 1996; Goodwin, 1998; Stoker, 1998; Jones and Little, 2000; Edwards et al, 2001; Pierre, 2000; Gaventa, 2004; and World Bank, 2004).

The result of the trend in regional policy to decentralize is far reaching, leading to many challenges. It has necessitated a paradigm shift from a top-down approach to one which relies on a bottom-up, integrative approach, involving many different partners: the State no longer assumes sole responsibility for governing. Crucially though 'government in most states retain control over the key policy levers' (Ayres and Pearce, 2008:540). This sea change to the implementation of policy relies on local assets and knowledge and has also placed pressure on tradition hierarchical administrative structures (OECD, 2005). It calls for a collective/negotiated approach which revolves around power relations as actors seek to influence the actions of others in order to pursue a particular agenda. This has not been without criticism and the literature would suggest that the capacity for communities to exercise genuine power is limited (Cooke and Kothari, 2001; Hickey 
and Mohan, 2004), asymmetric power relations prevail (Skelcher et al., 1996; Campbell and Marshall, 2000; Muir, 2004 and Somerville, 2005).

\section{Understanding power relations}

Power is central to our understanding of social relations within society and as a result it has attracted much attention within the literature. But the notion of power is not unproblematic. It is notoriously intangible and so it is hard to identify and measure. In the traditional sense, common usage of power refers to capacity to bring about change. Locke (1979) considers power as relational, being the capacity to make or receive any change. To which Lukes (2005) adds that it is also about being able to resist change.

While Lukes' himself has been critical of his own work (Lukes, 2005; 2006) many commentators have also identified shortcomings of his work (see for instance Hayward, 2000; Hindess 2006 and Shapiro, 2006). It is not intended to enter these debates here. Instead, this paper uses Lukes' concept of power, particularly the hidden third dimension, to understand the practice of regeneration within an empirical study.

Bachrach and Baratz (1962) claim that power has a private face that is evident in covert exclusion of the interests of particular groups. It is exercised through control or manipulation of the agenda, so that the very scope of decision-making is confined to particular issues. By providing a context for the manipulation of decision-making, the second face of power recognises the role of politics in social processes. Lukes (2005) 
claims that by limiting analysis to observable behaviour, whether overt or covert, the two-dimensional model does not go far enough. Power, he argues, relies on the capacity and the legitimacy to call on the obedience of others; it is about being able to influence the thoughts and desires of the victims without their being aware of its effects and so their real interests are suppressed. So although individuals may have the capacity to exercise power; they may choose not to do so (Barnes, 1988; Scott, 2001; and Lukes, 2005).

'Relations of power of the second and third dimension...can operate by generating gaps between preferences, wants, and real interests' (Ron, 2008:273). In other words people's very wants are a product of a flawed system. Consequently we need to 'search behind appearances for the hidden, least visible forms of power' (Lukes 2005:86). The dynamic process of uncovering real interests represents a complex relation between the power elite and the masses. This suggests that we need to consider individual relations and to critically examine the way in which actors are involved and situated in processes of governance. However the nature of the micro-relations that emerge among these new partners has to date only been given some recognition (Murtagh, 2001; Barnes et al., 2003; Scott, 2004; author, 2006, 2007; Derkzen et al. 2008) but has not yet been fully examined.

This understanding of power is based on community studies of power that emerged as a critique of American democracy in the 1950s (see for example Hunter 1953) and 
premised on the ideal of a community of autonomous persons. Individuals are discursive beings who endow social life with meaning and have the capacity to interpret and construct their social world and setting, rather than merely responding in a simplistic and automatic way to stimuli (Mead 1934; Cooley 1942; Blumer 1969). But these individuals will never be autonomous in the purest of senses. Power is connected to social structures (Giddens, 1984; Lukes, 2005). Traditions and discourses affect actors beliefs and actions, consequently agency is situated (Bevir and Rhodes, 2006). Power therefore relates to the capacity of agents to 'make a difference' and it is a structural property of society or the social community (Giddens, 1984:14).

\section{Decentralisation in England}

The Single Regeneration Budget (SRB) illustrates the complexity of the governance model. As part of the devolution process, English Government Offices and the Regional Development Agencies were given an enhanced role in delivering European and central government policies. Specifically in 1999 following their launch, Regional Development Agencies (RDAs) inherited a number of funding programmes such as Rural Priority Areas ${ }^{1}$ and the Single Regeneration Budget (SRB), incorporating the Rural Challenge Fund ${ }^{2}$. Taken together these programmes had in turn been governed by a variety of

\footnotetext{
${ }^{1}$ Formerly known as Rural Development Areas and managed by the Rural Development Commission, this operated using a partnership representing different stakeholders and providing funding for projects according to a strategic action plan and as such represented an integrated approach to rural development.

2 The RPA and SRB programmes were later terminated and funding streamlined to became a 'Single Pot' (DETR, 2002:12).
} 
central government agencies. Government Offices oversee the work of the RDAs, and in turn all GOs were managed by a central government department.

In the early days, many of the new RDAs were coming to terms with internal management issues and associated with the amalgamation of separate organisations. Simultaneously they were endeavouring to fulfil statutory requirements including administering funding programmes and publishing a Regional Economic Development Strategy (Regional Development Agencies Act 1998, 4.2). Decentralisation continues and in 2005 the Countryside Agency's rural economic and social regeneration work was transferred to the RDAs. Most recently the RDAs assumed responsibility for implementing this aspect of the new English Rural Development Programme (DEFRA, 2007).

\section{The case study}

The case study informing this paper was a Single Regeneration Budget (SRB) project, the Community Initiative. Twenty-five semi-structured interviews were conducted with professional practitioners and community representatives. A daily diary or research journal that focused on the 'behaviouristic' (Fielding, 1993:162) was maintained to record events at the lowest level of interference. This data was complemented by field notes, meeting papers, funding and policy papers and newspapers. Finally discussion occurred in informal ad hoc situations including prior to and following events. 
The overall research was conducted within an ethnographic framework that places emphasis on Weber's concept of verstehen; that is the subjective meaning that humans attach to their actions and interactions within specific social contexts (Elwell, 1996). Overt participant observation was used as the author was employed in a housing association, House, during the development of the project. This paper focuses on the early stages of the project development, from preliminary community planning to the establishment of structures to effectively implement objectives. The research placed emphasis on the process (see Author, 2008 for a fuller discussion of emergent methodological and process issues). This approach was vital in order to consider the 'latent conflict...between the interests of those exercising power and the real interests of those they exclude' (Lukes, 2005:28). Steps were taken to address issues of confidentiality through the use of pseudonyms (Van den Hoonaard, 2002).

It is important to state from the outset that this research assesses the practice of governance; it does not evaluate the Community Initiative in the conventional way. Judged by the SRB programme outcomes and outputs, the project was very successful: it levered in funding worth just over $£ 2 \mathrm{~m}$ over a 3 year period. Indeed it follows the pattern of many other projects that are deemed to be successful by funding agencies. It successfully undertook community consultation, ascertaining the views of local residents and subsequently established a project structure to implement the project plan. 


\section{The Single Regeneration Budget}

The Single Regeneration Budget (SRB) was a regeneration programme operational in England from 1994 to 2002. The central government body managing it, the then Department of Environment, Transport and the Regions ${ }^{3}$ (DETR), set broad parameters within which individual projects would operate by issuing national guidance for the SRB. This focused on delivery plans; project appraisal and approval; financial guidance; and monitoring and periodic review but was 'not intended to be a desk instruction for Partnerships and RDAs (Regional Development Agencies' DETR, 1999a:1). The programme emphasised the central role of local communities in regenerating their area with the aim 'to encourage local communities to develop local regeneration initiatives to improve the quality of life in their area' (DETR, 1997:3). Partnership, competition and hands-off management were also seen to be embedded in the SRB scheme (Rhodes et al., 2002). Locally based groups submitted proposals to their RDA. Successful projects were approved by a combination of regional and central government while the detailed procedures and day-to-day management arrangements were developed between the RDA and the SRB partnership, all within the confines of central government requirements. This decentralised approach continues to be used and is evident in schemes such as the European rural development programme (CEC, 2005) and the English framework for regeneration (Department for Communities and Local Government, 2008).

The Community Initiative

\footnotetext{
${ }^{3}$ Department of Transport, Local Government and the Regions (DTLR) took over regeneration funding in 2000, this responsibility was then transferred to DTI following the June 2001 election (www.dti.gov.uk). Most recently the Department for Business Enterprise and Regulatory Reform has responsibility for RDAs.
} 
The case study project, the Community Initiative is focused on two adjacent settlements in England, a village and a small town, with a combined population of approximately 20,000 and both having reasonable proximity to London. The village comprises an older style centre along with a newer London overspill settlement. The older part of the village consists of predominantly Victorian housing with facilities including a church, pub, barbershop and newsagents. Numerous community activities revolve round its Community Centre (built during the 1960s) and the drama theatre located in the upper school. Most residents travel to the adjoining market town for their weekly provisions and the town acts as an important employment, shopping and cultural centre for many more people from the rural hinterland. It has a variety of shops in the centre and many other facilities round about, including a leisure centre, restaurants, pubs and churches.

Fundamentally the regeneration partnership, the Community Initiative, was formed because at the time of conducting the research, although the village and the town contained $3 \%$ of the county's population, $20 \%$ of the poorest and most deprived wards in the county were found in this area. Furthermore it was affected by a general longterm lack of investment, lack of modern healthcare facilities and inadequate sewerage and drainage systems. A fatal fire on a council estate marked a watershed. Three different residents' groups placed pressure on the council to invest in their community. The District Council responded positively and two major changes ensued. One was the allocation of $£ 35,000$ per council house for refurbishment and fireproofing, totalling $£ 5 m$ over five years (Council Officer, 25.02.02). The other was the devotion of Council 
staff to the development of an SRB project to address deprivation within the community and to 'kickstart a larger programme of regeneration' (Council Officer, 25.11.99). This paper focuses on that project.

\section{Configuring the Community Project}

Partnership, a key concept in the governance, was at the heart of the Community Initiative. A fairly complicated structure emerged for this particular scheme with approximately 50 partners drawn from public, private and voluntary sectors including residents groups, local authorities, housing associations, health agencies and business groups, figure one below provides an overview. Partners were committed to realising the project objectives of 'social and economic capacity building', achieving 'improvements for the quality of life of the residents' and 'enabling all residents to participate fully in society' (SRB final bid).

Insert figure one

\section{The Board}

A working group that was instrumental in writing the SRB application was subsumed into the Board with additional members being co-opted to provide representation from parish, town, district and county councils and from the three different strands (see later for strand functions). There were no elections as individuals were co-opted by the council officers. Aside from the parish and town council representatives there was no 
individual on the Board whose membership was based on the fact that they lived in the area; they were all associated with a particular organization, agency or group.

\section{The Forum}

The Forum was initially used to consult with individuals from the community over the proposed content of the bid and so provided a mechanism that allowed members of the public to participate. In general about forty people attended these meetings. The meeting of 27.09.01 was themed 'Funding opportunities for voluntary organizations and community groups' (Forum minutes, 27.09.01) and its format illustrates a typical Forum meeting. It included informal presentations and information sessions from local and regional voluntary organizations. The meeting received an update of the ongoing work of the SRB project and oversaw the election of two representatives from the voluntary sector to the Board. It began with tea and coffee at $5.30 \mathrm{pm}$, with the formal business starting at $6 \mathrm{pm}$. Following an open question and answer session the meeting ended just after $7 \mathrm{pm}$.

\section{The Strands}

Three Strands were created encompassing the following themes: neighbourhood and community; health; and local economy and training. They were established to facilitate input from professionals and users to the Community Initiative. Their purpose is reflected in the invitation to the first community and neighbourhood strand meeting. Voluntary and community sector organizations were asked to participate to 'identify 
high priority needs' for their group and 'to ensure all relevant voluntary and community organizations are represented within the bid' (28.03.00).

\section{Regeneration rules: a help or a hindrance?}

The local authority faced a dilemma in dealing with three month period allowed within the programme between the acceptance of expression of interest and the submission of the final bid. It considered that this was insufficient time to engage with the number and variety of stakeholder interests, while also engaging in a meaningful way with the local community (Council Officer, 20.03.00). A working group was established by council officers and comprised of two council officers along with representatives from a local business forum, a rural development agency, a health organisation and a housing association (the author). The 'lack of knowledge and experience of effective multipartner delivery schemes' (council officer note to strand co-ordinators 14.07.00) instilled a certain degree of fear among local authority officers:

'[council officers] were pretty honest in admitting that the bureaucracy of this programme is crippling (26.09.00). Later the council officers questioned how the Community Initiative processes compared to other SRB bids, to get the response 'very rigorous to the point where we could be accused of being too cautious' from another member of the Board' (research journal, 14.12.00). 
Overall the technical skills required by of the financially accountable body (the council) were not insubstantial; they amounted to huge administrative obligations. Duties included receipt of and use of the final grant payment; establishing effective project appraisal and financial management systems; drawing up ongoing evaluation plans; establishing a project for post scheme evaluation; submission of quarterly reports and annual audited reports to the RDA (DETR, 1999a and b). Partnerships were required to demonstrate relationships with other schemes such as regional and national strategies, showing how the 'SRB contribution will enhance, reinforce and add value to other initiatives and public spending programmes' (1999b: para 1.5.1). Many of the obligations were depicted using technical phrases such as 'deed of novation' (1999a Annex 1D) 'key indicators of performance', 'milestones' 'quantifiable outputs', and 'exit strategy' (1999a:para5.1), so that '[the RDA] recognises that there is a significant learning curve for everyone involved in this new SRB project' (Board minutes, 14.12.00). This created substantial challenges not least of which was the act of juggling bureaucracy with operational responsibilities.

'We [SRB Board] had a difficult dilemma over the process being pulled from a number of directions: being accountable, having systems in place whilst also getting on with the task in hand' (30.11.00).

As the act of regeneration is technical rather than political (Taylor, 2003), we have evidence of a process where the agents of the elite, i.e. those creating regeneration 
programmes, devise a structure that maintains the power of the ruling elite, i.e. the policy makers and the central state (Mills, 1956). Meanwhile the parameters of policy are established elsewhere (Taylor, 2003, Jones, 2003), consequently the rules do not necessarily assist the process.

(Re)Creating (elite) structures.

Guidance material did not compel partnerships to be led by local councils. Their predominant role was promoted 'the RDA can only enter into a funding agreement with a legal entity capable of meeting the liabilities that flow from the conditions of grant' (DETR, 1999a: para 8.1) supporting the notion that the rules of engagement in partnerships rest firmly with the elite (Bochel, 2006).

The supremacy of the public sector, and the power wielded by it, was further evidenced by the way in which capacity building was addressed. The SRB guidance provides a section on 'Community Capacity Building' (DETR, 1999b: para: 1.4.7), there is no similar section for other partners such as those from the public sector. And in case there is any doubt on this, the meaning of capacity building is spelled out as 'activities to increase the capacity of local communities to contribute to regeneration and the strengthening of the social fabric, for example through training of staff and volunteers in community groups, through the strengthening of networks, forums or representative structures' (DETR. 1999a: Appendix one, output 8F). It is notable that this contrasts with international development programmes where funding is provided to local government 
in Chile, Honduras, Bolivia and Zambia specifically to build their capacity to effectively develop local-level initiatives (Babajanian, 2005). By assuming that capacity building is only required by certain partners in the SRB programme, even though the literature suggests otherwise (see for instance Mannion, 1996, Taylor 2000 and Scott, 2004), the evolving structures implicitly underpin the superiority of public sector approaches. There is little encouragement of change to their institutional practices through involvement in the programme. This inherent assumption of organisational superiority is a symptom of the privileged ruling stratum; it is part of the ideology of the elite (Mills, 1956).

Further the officers effectively established a blueprint that duplicated the council culture within the partnership. Officers claimed that they could not 'simply put the project in the control of another organisation' (Council Officer, 23.08.00). In fact they proposed recruiting a secondee from their organisation to the post of the project manager. Reminiscent of Katz's claim that policy elites successfully define ideal types of organisational structures (1975), the Forum was told that 'the process [for managing the money] is now being finalised with [the] District Council' (07.03.01). The Council paper 'Proposed Administration and Delivery Structure' (03.08.00) clarifies its central role asserting that: 
'ultimate decision making powers lie with [the] District Council as they are the financially accountable body, but they will be advised by the Management Board, who will in turn be informed by the three Strands and the Consultation Forum'(24.08.00).

Somerville considers that the moulding of citizens in their own image or 'responsibilisation' reinforces and reproduces elite power (2005:125). Such 'mimetic isomorphism' (DiMaggio and Powell, 1983:150) is yet another example of Lukes' third dimension of power (2005). Participants in programmes are not necessarily aware of this subtle form of manipulation, and even if they are, their ability to affect change is questionable.

Council officers in the Community Project had an inflexible view of power relations. Implicitly they understood power in the Weberian tradition as a zero sum game, if they handed power over to community representatives; they believed their own control would be eroded. They did not conceive of power as something that could be tapped into and mobilised by the collective whole for the greater good (Parsons, 1960; Mann, 1960).

\section{Achieving participation and managing expectations}

Given the time constraints associated with the bidding schedule, the working group took a pragmatic decision to use existing networks and connections to kickstart the 
consultation process on the basis that wider and deeper participation would follow. The forum chairman stated that

'the partnership must not be exclusive and although 30 organizations have been invited to the meeting, there will be other important organizations who will hopefully wish to become involved and that one of the purposes of the discussion groups would be to identify other contributing partners' (Forum minutes 22.03.00). Meanwhile council officers urged agencies that

'If you can identify any group that you feel should be invited please feel free to copy this letter to them' (28.03.00). But it remained difficult to attract new individuals to the process:

'Despite a free buffet, not much interest was shown, with few new faces at the meeting' (research journal, 11.04.00).

The fledgling partnership faced the 'revolving door syndrome' (Taylor, 2000:1020) where usual suspects, rather than disenfranchised groups, are primarily involved.

Even those who were involved more fully were dubious about their capacity to exert influence. They believed that ultimately the Council was in control of the key decisions and so they were unable to influence the project anyway. 
'But we're not really involved in this project. It's one of your schemes isn't it? I mean, we're not making decisions about how the money is spent are we?' (local resident, 20.03.00)

There was a feeling of 'remoteness' from the project and a tenant liaison officer stated that 'it is not clear how it fits with the other activities, it has been pigeonholed. Stronger links with the refurbishment scheme [i.e. the revamping of the council estate] would be useful' (Council Officer 25.02.02).

While the Forum appeared to advance wide participation closer scrutiny reveals its controlled and limited nature and indeed of the overall project. To paraphrase Mills (1956), even though the residents of the area were living in a time of big decisions; they were not making any. For example many of the attendees to the Forum consultation meetings expressed concern over the threatened closure of the local hospital. They clearly believed that this was the appropriate vehicle to raise the matter and did so during the question and answer slot. They failed to understand that Forum consultations were part of a distinct participatory process bounded by the SRB rules. The council officer attempted to explain: 
'I know the threatened hospital closure is very important to everyone here. But I'm afraid we can't provide funding for that. What we can do is support the wide range of projects that are outlined in the bid document' (22.03.00).

Participation was an output of the regeneration programme, 'slotting' into predetermined and externally defined aims (Oakley, 1991; Jones, 2003), rather than a process that also ascertained views and shaped the bid. If we consider power 'in terms of agents' abilities to bring about significant effects, specifically by furthering their own interests and/or affecting the interests of others, whether positively or negatively' (Lukes, 2005:65), then these actors were not empowered. The content of the meeting was highly prescribed; there was little room to veer away from SRB activities.

Repeated studies of community involvement have shown how communities have generally remained on the margins of power in partnership arrangements (Taylor, 2007; Hastings, 1996; Bochel, 2006; Gilchrist, 2006). While accepting the naivety of the assumption of a single community interest (Edwards, 1997; Muir and Rhodes, 2008); failing to give the wider 'community' an opportunity to take up positions of influence lessens the status of the partnership. A further danger with this approach according to Wood et al. (2001 cited in Hayward et al. 2004) is that views can be represented quite differently when filtered through representatives compared to when they are expressed directly. Participation for the council officers was clearly a restricted affair and was not 
something that was widely available for all actions. And so public accountability is sharpened rather than public participation enhanced (Newman, 2001).

\section{Covert power}

There was evidence of the exercise of covert power (Bachrach and Baratz, 1962, Lukes, 2005). The local authority officer described the purpose of the consultation meeting:

'[T]he question we are discussing tonight relates to the contents of the SRB application that is to be submitted. This will not be an easy process but we can work together to identify priorities and to put in a shared bid' (14.10.99).

In a genuine consultation, the question would have been phrased differently. It might have asked 'Do people wish the Council to put resources into the SRB?' Effectively the question of whether or not an application would be made was not up for discussion the scenario was presented as an 'opportunity not to be missed' (research journal, 12.10.99). People were therefore given the opportunity to participate in a limited exercise, that of developing a bid to the SRB and the restrictions that this entailed. Hence a barrier was immediately created preventing people who did not agree with this use of local authority resources from entering the debate. Powerful individuals (namely the working group) limited the scope of debate to issues that were comparatively harmless to their interests. 
The consultation with the community therefore legitimated a previously made decision made by the local authority to make a submission to the SRB programme. The discussion was limited to the form of the bid rather than concentrating on whether or not a bid should be made in the first place. In confining decision-making to particular issues, covert power was exercised (Bachrach and Baratz, 1962); real interests were not identified or discussed. As a result a sympathetic and unproblematic public representation that was viewed as serving the general interest followed and was met with little opposition. In actual fact power was exerted within the restricted area of the working group where access was limited to social and political elites (Woods, 1998a and 1998b). These backstage spaces are located away from the formal decision making processes, intervention from opponents or the constraints of regulation. The wider forum was powerless as it approved a decision made by certain individuals rather than the community. Hidden power was evident as those outside control were not only omitted from the political process but they were denied entry (Lukes, 2005). Although they were able to become involved in the forum and strand meetings, they were not invited to join the working group and thereby to participate in the restricted area.

\section{Individual positions of power}

As the Community Initiative progressed and in the course of discussions with council officers, it became clear that they viewed the author as a safe choice for key positions within the project structure. She was one of two co-ordinators of the Community and Neighbourhood Strand that were hand-picked by the Local Authority Officers involved 
in the project. The Officers were looking for individuals with whom they could work as well as people with useful skills and contacts:

'My background is in council led business programmes. Engaging with the community was quite novel for me and I went through a steep learning curve. I was glad to have [the author] there to share consultation techniques' (Council Officer, 25.02.02).

Originally the author resisted the position of Strand co-ordinator, but eventually agreed to do it in the short term:

'[Council Officer] would like me to continue with co-ordinating community/social strand (alongside [the rural regeneration agency]). I am happy to do this...I also suggested to [Council Officer] that the [Community Initiative] management group should have a 'voluntary representative' as it is purely made up of paid staff. Interesting to hear his comments, he does not want a lot of controversy and he considers that this might make things "tricky"' (research journal, 23.08.00).

Similarly individuals for the working group were handpicked on the basis of a number of factors, as articulated by council officers to the author:

'Knowledge, guidance and the ability to signpost to other agencies was an invaluable contribution from [your project]. This went hand-in-hand with you as an individual. If a 
different person had been running the project, we might not have had this link' (Council Officer, 24.02.02).

'We had some limited experience of consultation and public engagement. It was useful to have your input. Your contribution to the debate around neighbourhood renewal was helpful as well as your role in pushing and developing this' (Council Officer, 25.02.02).

Dahl (1961:226) outlines various sources of power in social relations including access to money, information, social standing, charisma and legitimacy. The author's position was valued in part due to her position; specifically this was the 'prestige' (Mills, 1956:82) of her employer's position in the regeneration sector and the fact that House was 'well connected' as a result of links with powerful funding and policy bodies (Council Officer, 25.02.02). But it also arose from the knowledge and contacts that the author possessed and the fact that the officers knew that they could work with her personally. Power was 'distributed by the various enduring structural relationships in society and exercised by individuals and groups based on their location in a given structure' (Isaac, 1987:28).

\section{Creating an elite space?}

Complex forms of power are being used to affect change via governance initiatives. Whereas policy ideals of maximum participation and equal power relations prevail, it may be the case that structures employed enable a certain type of participation depending on the degree of 'insiderness' and relating to degrees of access and influence 
(Maloney et al., 1994:26). To paraphrase Lukes (2005), the powerful [public sector] agents derive their capacity and legitimacy from structures to call on the obedience of less powerful [community and voluntary sector] agents.

Public participation is a limited activity; it constrains particular voices. It is also restricted by the individuals who choose to get involved and so it is limited in terms of what it is able to achieve. Agents are in turn constrained by the structure of the funding framework so that while they are able to freely express their ideas and beliefs, to remain involved and to participate they must abide by the complex rules of the game; they must operate within pre-determined boundaries. This is not a 'popular space' that emerges from within and is defined by the community; it is an 'invited space' of governance in that it is an arena created and defined by government and is one into which communities are invited by the state (Cornwall, 2004).

Further, and crucially, the practice of regeneration exhibits many of the symptoms of an elite activity (Mills, 1956). It is a technical rather than a political process. It is determined and controlled by a clique of policy makers and their corresponding agents resulting in a process that does not necessarily correlate to the needs, skills or indeed the culture of the wider of the community that it purports to represent. It is important to assert that this does not necessarily appear as a failure; indeed the Community Initiative was very positive for the communities involved. However those outside the elite circle were 
confined to the margins and so their particular agendas were sidelined as administrative concerns or projects that were deemed feasible by the regulations took precedence.

On the surface this would seem to correlate to Lukes' understanding of power (2005:65). It relates to agents' (primarily the local authority, but also the elite working group) bringing about considerable effects by both furthering their own interests while in this case also affecting the interests of others (the individuals and groups that got involved in the [SRB Project]). It remains unclear the extent (positively or negatively) to which the real interests of others were affected. What is crucial to this research is the fact that an elite group retained control of the parameters of governance, affecting the real interests of the masses. And so following from Ron (2008), specific regeneration schemes can only represent some interests, while others' are not identified; the real interests of the masses are ignored or marginalised. Community planning and ultimately regeneration schemes are in danger of becoming inert and impotent (Williams, 2004) and ultimately potential achievements curtailed. This is critical given the increasing emphasis on this type of approach in a policy environment seeped in governance.

\section{Final comments}

On the one hand in this age of public accountability and scarcity of resources, it might be completely unrealistic and idealistic to consider that a community can have responsibility for entirely setting its own agenda, free from constraints, to determine endlessly the types of activities in which it can engage. Indeed sceptics might well 
exclaim, so what, regeneration works and involves representation from 'the community'. This is true and it has many positive attributes. On the other hand its limitations must be acknowledged if persistent inequalities and marginalisation are to be addressed. If an elite group operate within an invited space and purport to represent broader interests it is entirely misleading to set up these structures and systems of governance and claim that they are acting wholly in the real interests of the community. While positive benefits to a community typically emerge, it is vital that the central role of the state in shaping the outcomes is recognised. As such the very nature of participation does not necessarily allow for real interests to be identified. Current models are in danger of over-stating their potential. Perhaps more importantly an elite regeneration community is being situated within a space that has more traditionally been inhabited by dissension. Subsequently the oppositional space is at risk of being marginalised.

This paper set out to evaluate arrangements for processes of governance with particular reference to power. In keeping with existing literature it shows how the state agenda is firmly etched in new governance spaces (Swyngedouw, 2005; Taylor, 2007). This is manifest through elite groups of individuals who use their power to pursue specific agendas. The complex web of governance needs to create space for bottom-up development to avoid dominance of the interests of the state and of elite community interests. If there is to be any possibility of meaningful engagement with a community and of addressing issues of inequality, community participation must be perceived not 
as a one-off proposition, instead it should be viewed as an ongoing process. Clearly the usual requirements of time and resources are necessary. But more than this policymakers need to pay heed to the limitations of current governance structures and seek ways of engaging with communities whose interests may fall outside of invited spaces. It may be that mainstream policy instruments assume this responsibility, but this has to be recognised. If not, Ron's claim that 'a community understands its own problems through frameworks that are in fact inadequate to address its own goals' is in danger of being realised (2008:4).

To conclude, policymakers need to become attuned to the popular spaces that communities create for themselves. Otherwise existing and emerging structures of governance, while exhibiting all of the characteristics of success, can only pay lip service to the real interests of local communities. All the while risky community ventures remain pipe-dreams. Further, government may well assume an uncontested position as the regeneration elite overshadow a space that has to date been a domain for challenging the state. 


\section{References}

Ayres, S and Pearce, G. (2008) Transforming regional governance in Europe. Policy and Politics Vol. 36 No. 4 pp. 539-44.

Babajanian, B. V. (2005) Promoting community development in post-Soviet Armenia: The social fund model. Social policy and administration Vol. 39, no. 4, pp. 448- 462.

Bachrach, P. and M.S. Baratz (1962) The two faces of power. American Political Science Review 56 pp. 947-952

Barnes, B. (1988) The nature of power. Cambridge: Polity Press in association with Oxford: Basil Blackwell

Barnes M., J. Newman, A. Knops and H. Sullivan. 2003. Constituting 'the public' in public participation. Public Administration, Vol. 81.2 pp. 379-399.

Bevir, M. and Rhodes, R. A.W. (2006) Defending interpretation. European Political Science 5 pp. 69-83.

Blumer, H. (1969) Symbolic interactionism: perspective and method (Englewood Cliffs, NJ: Prentice Hall) 
Bochel, C. (2006) New Labour, participation and the policy process. Public Policy and Administration. Vol. 21 (4) pp.10-22.

Campbell, H. \& Marshall, R. (2000) Public involvement in planning: looking beyond the one to the many. International Planning Studies, Vol. 5 No.3, pp. 321-344.

Commission of the European Communities (CED) (2005) COUNCIL REGULATION (EC) No $1698 / 2005$ on support for rural development by the European Agricultural Fund for Rural Development. (EAFRD) OJ L277 pp. 1-40.

Connelly, S. and Richardson, T. (2004) Exclusion: the necessary difference between ideal and practical consensus. Journal of Environmental Planning and Management Vol.47 No.1 pp.3-17.

Cooke, B. and U. Kothari. (2001) The Case for participation as tyranny in Cooke, B. and U. Kothari. (eds) Participation: the new tyranny? London: Zed Books pp. 1-15.

Cooley, C.H. (1942) Social organisation (Dryden Press, New York)

Cornwall, A. (2004) New democratic spaces? The politics and dynamics of institutionalised participation. IDS Bulletin, 35(2) pp.1-10. 
Dahl, R. A. (1961) Who governs? Democracy and power in an American City. New Haven, CT: Yale University Press.

Department for Communities and Local Government (2008) Transforming places; changing lives. A framework for regeneration: London: HMSO

Department for Environment, Food and Rural Affairs (2007) Rural Development Programme for England 2007-13. London: HMSO.

Department of Environment, Transport and the Regions (DETR) (1997) SRB Challenge Fund: a handbook of good practice in management systems. London: HMSO.

DETR (1999a) Single Regeneration Budget: Guidance Manual. London: HMSO.

DETR (1999b) Single Regeneration Budget: Round Six Bidding Guidance. London: HMSO.

Derkzen, P., Franklin, A., and Bock, B. (2008) Examining power struggles as a signifier of successful partnership working: A case study of partnership dynamics. Journal of Rural Studies Vol. 24, No. 4, pp. 458-466. 
Derkzen, P. and Bock, B. (2009) Partnership and role perception, three case studies on the meaning of being a representative in rural partnerships. Government and Policy Vol. 27 No.1 pp.75-89.

DiMaggio, P. and Powell, W.W. (1983) The iron cage revisited: institutional isomorphism and collective rationality in organizational fields. American Sociological Review Vol. 48 pp. 147-160.

Edwards, B., M. Goodwin, S. Pemberton, and M. Woods. (2001). Partnerships, power, and scale in rural governance Environment and Planning C: Government and Policy, Vol. 19 pp.289-310.

Elwell, F., (1996) The Sociology of Max Weber, April 15, 2004, http://www.faculty.rsu.edu/ felwell/Theorists/Weber/Whome.htm

Fielding, N. (1993) Ethnography in Gilbert, G.N. (ed.) Researching Social Life. London: Sage pp. 154-171.

Giddens, A. (1984) The Constitution of Society. Cambridge: Polity Press.

Gilchrist, A. (2006) Partnership and participation: power in process. Public Policy and Administration 21 (3) pp. 70-85. 
Goodwin, M. 2006. Multi-level governance in rural UK: recent debates. Paper presented to ESRC New Rural Economies Seminar Series 13/01/06.

Hajer, M.J. and Wagenaar, H (2003) Introduction in Hajer, M.J. and Wagenaar, H. Deliberative policy analysis. Understanding governance in the network society pp.1-30. Cambridge: Cambridge University Press.

Hastings, A. (1996) Unravelling the Process of 'Partnership' in Urban Regeneration Policy. Urban Studies, Vol. 33, No.2 pp. 253-268.

Hayward, C.R. (2000) De-facing power. Cambridge: Cambridge University Press.

Hayward, C., Simpson L. and Wood, L. (2004) Still left out in the cold: Problematising participatory research and development. Sociologia Ruralis Vol. 44.1 pp.95-108.

Hickey, S. and Mohan, G. (2004) Towards participation as transformation: critical themes and challenges, in S. Hickey and G. Mohan (eds) Participation: From Tyranny to Transformation pp. 3-24. London: Zed books. 
Hindess, B. (2006) Review symposium on Steven Lukes' Power: A Radical View

Bringing States Back In. Political Studies Review Vol. 4 p 115-123.

Hoonaard, W.C. van den (2003) Is anonymity an artifact in ethnographic research? Journal of Academic Ethics 1 (2) pp. 141-151

Hunter, F. (1953) Community power structure. Chapel Hill: University of North Carolina.

Isaac, J.C. (1987) Beyond the three faces of power. Polity Vol.10. No.10 pp.4-31

Jessop, B. (2002) The future of the capitalist state. Polity: Cambridge.

Jones, P. (2003) Urban regeneration's poisoned chalice: is there an impasse in (community) participation-based policy? Urban Studies 40(3) pp.581-601.

Jones, O. and J. Little. 2000 Rural Challenge(s): partnership and new rural governance. Journal of Rural Studies, Vol. 16 pp.171-183.

Katz, M.B. (1975) Class, Bureaucracy and Schools: The illusion of educational change in America. New York: Berger 
Locke, J. (1979[1690]) An essay concerning human understanding ed. Nidditch, P.H. Oxford: Clarendon Press.

Lowndes, V. and Skelcher, C. (1998) The Dynamics of Multi-organisational Partnerships: An Analysis of Changing Modes of Governance. Public Administration Vol. 76, pp. 313333.

Lukes, S. (2005) Power: A radical view $2^{\text {nd }}$ expanded. edn. London: Palgrave Macmillan. $1^{\text {st }}$ edn., 1974

Lukes, S. (2006) Reply to Comments pp. 164-173. Political Studies Review Vol. 4 Maloney, W.J., Jordan, G. and McLaughlin, A. (1994) Interest groups and public policy: the insider/outsider model revisited. Journal of Public Policy 14 pp.17-38.

Mann, M. (1986) The sources of social power, vol.1: A history of power from the beginning to AD 1760. New York: Cambridge University Press.

Mannion, J. (1996) Partnership, participation and capacity building: rural development based on bottom up strategies. LEADER Magazine No. 12 pp. 6-10. 
Mead, G.H. (1934) Mind, self and society from the standpoint of social behaviourism. University of Chicago Press, IL: Chicago

Mills, C.W. (1956) The Power Elite. New York : Oxford University Press.

Miraftab, F. and McConnell, E. D. (2008) Multiculturalizing Rural Towns-Insights for Inclusive Planning. International Planning Studies Vol. 13, No. 4, pp.343-360.

Muir, J. (2004) Public participation in area-based urban regeneration programmes. Housing Studies, Vol. 19 No. 6 pp.947-66.

Muir, J. and Rhodes, M.L. (2008) Vision and reality: community involvement in Irish urban regeneration. Policy and Politics Vol. 36 No. 4 pp.497-520.

Murdoch J. and Abram, S. (1998) Defining the Limits of Community Governance. Journal of Rural Studies, Vol.14 No.1 pp.41-50.

Murdoch, J. and Ward, N. (1997) Governmentality and territoriality: The statistical manufacture of Britain's 'national farm', Political Geography 16, 307-24.

Murtagh, B. (2001) Partnerships and Area Regeneration Policy in Northern Ireland, Local Economy. Vol.16 No.1, pp.50-62. 
Newman, J. (2001) Modernising Governance: New Labour, Policy and Society. London: Sage.

Oakley, P. (1991) Projects with People. The practice of participation in rural development. International Labour Office (via Intermediate Technology Publishing, London).

OECD (2001) Local Partnerships for better governance. Paris: OECD.

OECD (2005) Modernising Government. The Way Forward. Paris: OECD.

Parsons, T. (1960) The distribution of power in American society in T. Parsons Structure and process in modern societies pp. 199-225. Glencoe, IL: Free Press.

Pearce, G., Ayres, S. and Tricker, M. (2005) Decentralisation and devolution in the English regions: Assessing the implications for rural policy and delivery. Vol. 21 pp.197212.

Peters, B. G. and J. Pierre (2001) Developments in Intergovernmental Relations: Towards Multi-level Governance. Policy and Politics, 29, 2, 131-5. 
Pierre, J. (2000) Introduction: understanding governance in Pierre, J. (ed.) Debating Governance: authority, steering and democracy. Oxford University Press pp.1-12.

Raco, M., Parker, G., and Doak, J. (2006) Reshaping spaces of local governance?

Community strategies and the modernisation of local government in England.

Environment and Planning C: Government and Policy Vol. 24 No.4 pp.475 - 496.

Ron, A. (2008) Power: A pragmatist, deliberative (and Radical) View. The Journal of Political Philosophy Vol. 16 No. 3 pp 272-292.

Rhodes, J., Tyler, P., Stevens, S., Warnock, C. and Otero-Garcia, M. (2002) Lessons and evaluation evidence from ten Single Regeneration Budget case studies. Mid term report. Department of Land Economy, Cambridge for DTLR. London: HMSO.

Rhodes, R.A.W. (1997) Understanding Governance: policy networks, governance, reflexivity and accountability. Buckingham: Open University Press.

Scott, J. (2001) Power. Cambridge: Polity Press.

Scott, M. (2004) Building institutional capacity in rural Northern Ireland: the role of partnership governance in the LEADER II programme. Journal of Rural Studies Vol.20 pp.49-59. 
Shapiro, I. (2006) On the Second Edition of Lukes' Third Face Political Studies Review Vol. 4 pp. 146-155.

Shortall, S. (2004) Social or economic goals, civic inclusion or exclusion? An analysis of rural development theory and practise. Sociologia Ruralis Vol. 44 No.1 pp. 109-123.

Shortall, S. (2005) Participation, community development and social exclusion. Paper presented to ESRC New Rural Economies Seminar Series 25/11/05.

Skelcher, C., McCabe, A and Lowndes, V. (1996) Community networks in urban regeneration: 'It all depends who you know...!', Bristol: The Policy Press.

Somerville, P. (2005) Community governance and democracy. Policy and Politics Vol. 33.1 pp.117-144.

Stoker, G. (1998) Governance as theory: five propositions. International Social Science Journal No. 155 pp.17-28.

Storey, D. 1999. Issues of Integration, participation and empowerment in Rural Development: The case of LEADER in the Republic of Ireland. Journal of Rural Studies, vol. 15. No. 3 pp. 307-315. 
Swyngedouw, E. (2005) Governance innovation and the citizen: the Janus-face of governance-beyond-the-state. Urban Studies Vol.42(11) pp. 1991-2006.

Taylor, M. (2000) Communities in the Lead: Power, Organisational Capacity and Social Capital Urban Studies Vol. 37 No.5-6 pp. 1019-1035.

Taylor, M. (2003) Neighbourhood governance: Holy Grail or poisoned chalice? Local Economy, Vol. 18 No. 3 pp. 190-195.

Taylor, M. (2007) Community participation in the real world: opportunities and pitfalls in new governance spaces. Urban studies Vol. 44 No.2 pp.297-317.

Tendler, J. (1997) Good Government in the Tropics. Baltimore and London: Johns Hopkins University Press.

Williams, J.J. (2004) Citizenship, Community Participation and Social Change: The Case of Area Coordinating Teams in Cape Town, South Africa. IDS Bulletin, 35(2) pp.19-25.

World Bank (2004) Local development discussion paper. Prepared for the International Conference on Local Development, Washington, DC: World Bank, 16-18 June. Available 
at http://www1.worldbank.org/sp/ldconference/Materials/LDDPFinal.pdf, last accessed 31.07 .08

Hayward, C., Simpson, L. and Wood, L. (2004) Still left out in the cold: Problematising participatory research and development. Sociologia Ruralis, Vol. 44 No.1 pp.95-108. 